\title{
Shoulder joint mobility in patients with primary adhesive capsulitis after treatment with continuous mode of ultrasound: A systematic review of randomized controlled trials
}

\author{
Sumanta Saha*1, Sujata Saha² \\ Received: 8 Apr 2019 \\ Published: 21 Dec 2019
}

Abstract

Background: Although the continuous mode of ultrasound therapy improves joint mobility, its role in primary adhesive capsulitis (AC) remains unclear. Therefore, this systematic review aims to address this evidence gap.

Methods: The literature search included databases (SCOPUS, CINAHL, EMBASE, and PubMed) and in-text references of articles read full-text. Randomized controlled trials (RCT) on primary AC patients (published in the English language between 1979-2019) comparing the ROM changes (in degrees) mainly between continuous mode of US therapy with any other non-electrotherapeutic treatment were eligible for inclusion. The trials were reviewed narratively along with an assessment of the risk of bias.

Results: Out of 174 search results, two eligible single-center trials comprising of 100 participants compared ROM in four separate directions at the 10th session and after three months post-intervention. The risk of selection bias, performance bias, and attrition bias was unclear among the trials. While in both the trials ROM (in all directions) improved in the respective intervention groups at follow up, most of these changes varied between the intervention groups in one trial. However, in the latter trial, participants in the treatment group had the worst ROM values at baseline with poor compliance to the adjunct exercise therapy.

Conclusion: The contemporary evidence in the context remains inconclusive due to a lack of large multicentric well-conducted RCTs.

Keywords: Adhesive capsulitis, Continuous mode, Ultrasound, Range of motion, RCT

Conflicts of Interest: None declared

Funding: None

\section{*This work has been published under CC BY-NC-SA 1.0 license. \\ Copyright $\odot$ Iran University of Medical Sciences}

Cite this article as: Saha S, Saha S. Shoulder joint mobility in patients with primary adhesive capsulitis after treatment with continuous mode of ultrasound: A systematic review of randomized controlled trials. Med J Islam Repub Iran. 2019 (21 Dec);33:144. https://doi.org/10.47176/mjiri.33.144

\section{Introduction}

Adhesive capsulitis (AC) is an inflammatory condition of the glenohumeral joint capsule that affects $2-5 \%$ of the population $(1,2)$. Females aged 40-60 years old are frequently affected by $\mathrm{AC}(1,2)$. AC can be either primary (idiopathic) or secondary (due to other shoulder pathologies like rotator cuff tears, calcific tendinitis, arthritis of

\footnotetext{
Corresponding author: Dr Sumanta Saha, sumanta.saha@uq.net.au

1. National Institute for Research in Tuberculosis, India

2. Mankar College, West Bengal, India
}

glenohumeral joint or acromion-clavicular joint and cervical radiculopathy) (3).

Limitation of shoulder joint mobility is one of the chief morbidities of AC; both active range of motion (ROM) and passive ROM loss can occur in different directions (1, $3,4)$. As AC advances, the shoulder joint ROM declines

$\uparrow$ What is "already known" in this topic:

Evidence suggests, continuous mode ultrasound improves joint motion. However, little is known if it increases shoulder joint kinesis in primary adhesive capsulitis patients.

\section{$\rightarrow$ What this article adds:}

In primary adhesive capsulitis, the current evidence regarding the continuous mode of ultrasound therapy and the improvement of shoulder joint mobility remains inconclusive. New multicentric clinical trials with high statistical power and low risk of bias are needed to generate constructive evidence in this context. 
progressively and leads to stiffness (1). Restricted ROM in AC patients can cause difficulty with daily self-care activities like dressing, fastening the brassiere, hair combing, reaching the back pocket (3). Although AC is a selflimiting condition, many patients do not regain their lost ROM completely $(2,5)$.

Unfortunately, at the present day, there is no consensus about the ideal treatment for $\operatorname{AC}(1,2,4,5)$. To improve the kinesis of the affected shoulder joint, AC patients often receive ultrasound (US) therapy (an electrotherapeutic modality) (6). The heat delivered by the continuous mode of US alters the cell membrane permeability, accumulates calcium inside cells, and stimulates tissue regeneration (7). The frequency of therapeutic US delivery is $1-3 \mathrm{MHz}$ (8). Research suggests that the therapeutic US delivered in continuous mode improves joint mobility (9-11). However, the contemporary evidence of its usefulness in primary $\mathrm{AC}$ patients in improving the shoulder joint ROM is not rigorous. Therefore, to address this knowledge gap, this systematic review was conducted. This study aimed to compare, the therapeutic effects of the continuous mode of US alone or in combination with non-electrotherapeutic treatment/s versus placebo and (or) non-electrotherapeutic treatment/s on shoulder joint ROM in primary AC patients.

\section{Methods}

This review does not have a pre-registered protocol. Studies meeting the following eligibility criteria were eligible for inclusion in this review. 1- Primary AC patients, aged 18 years and older, suffering from the shoulder joint movement restriction to any extent for any duration were eligible. As per the trialists' definition, we accepted the primary AC diagnosis. 2- Randomized controlled trials (RCT) of any design (like parallel, cross-over), published in the English language between Feb 1979 to Feb 2019, were eligible. Since, from 1990 the use of therapeutic US surged in several nations (12), we decided to search for papers published up to about a decade back (until 1979). 3 - Trials in which the intervention group were treated with the continuous mode of US therapy in any dose for any duration as a sole treatment or in combination with any non-electrotherapeutic conservative treatment/s (e.g., analgesics and anti-inflammatory medications, exercise therapy and hot packs). 4- Trials that administered any of the following treatments for any duration to the control group - the sham US and (or) any conservative nonelectrotherapeutic modality (e.g., analgesics and antiinflammatory medications, exercise therapy and hot packs). A study was identified as an RCT when the participants were recruited using pre-defined eligibility criteria, then randomly allocated into an intervention and control group, and finally, both groups were followed prospectively to compare the outcomes. 5- RCTs that reported the active or passive shoulder joint ROM in different directions (the outcome) in degrees, after the compared treatment groups have received the interventions. We excluded studies of an observational design and when participants had a systemic cause of shoulder joint pain (like rheumatoid arthritis, diabetes mellitus).
To identify eligible trials, we searched the electronic databases (PubMed, CINAHL, EMBASE, and SCOPUS), and the last date of the search was 21-Feb-2019. Additionally, we scanned through the references of the publications we read full-text. The electronic databases were searched for titles and abstracts of research papers. The following search terms were used - "adhesive capsulitis" OR "frozen shoulder" OR "stiff painful shoulder" OR periarthritis AND ultrasound. We further narrowed down the search results to identify RCTs by applying the "randomized controlled trial" filter or by using the word 'trial' if a filter was not available.

After eliminating the duplicates, using the abovementioned eligibility criteria, we skimmed through the titles and abstracts of the searched papers. We read papers in full-text when the studies seemed to meet the eligibility criteria or when a decision about inclusion or exclusion was not possible by reading the abstracts alone. We adhered to the study selection process of the PRISMA flow diagram (13).

From each trial, we extracted the following information: 1. Study profile (last name of first author, year of publication, country of study) 2. Study population data (sample size, number of dropouts and its cause, age, mean (and SD) age, average (and SD) of symptom duration, sex, inclusion and exclusion criteria) 3. Intervention details (of treatment group and comparison group) 4. Trial methodology (study design, recruitment, blinding, analysis) 5 . Outcome relevant information (outcome assessed, time points of outcome assessment after intervention, relevant results) 6. Miscellaneous info (funding source, ethical approval, participant consent). We did not contact the trialists for any information.

To assess the risk of bias in individual studies, we used the guideline described in the Cochrane Handbook for Systematic Reviews of Interventions Version 5.1.0 [updated March 2011] (14). Risk of bias was assessed in the following domains - selection bias (sequence generation, concealment of allocation), performance bias (blinding of study participants and personnel involved, blinding of outcome assessors), attrition bias (incomplete reporting of outcome data), reporting bias (selective reporting of the outcome), and miscellaneous sources of bias (14). Based on the risk assessment, each component of the risk of bias was labeled as low risk, high risk, or unclear risk (when neither of the former was applicable) (14). Disagreements among authors were resolved by discussion.

Due to the scarcity of eligible trials, a meta-analysis was not done. Henceforth, we report this paper narratively. We followed the PRISMA guideline to report this paper (13).

\section{Results}

The electronic database and hand search generated 174 (71 in SCOPUS, 44 in CINAHL, 36 in EMBASE, and 23 in PubMed) and four search results (papers) respectively. We skimmed through the titles and abstracts of 141 papers after excluding the duplicates. Then, six papers were read full-text, and finally two RCTs $(15,16)$ matching our study's eligibility criteria were included for the review (Fig. 1). 


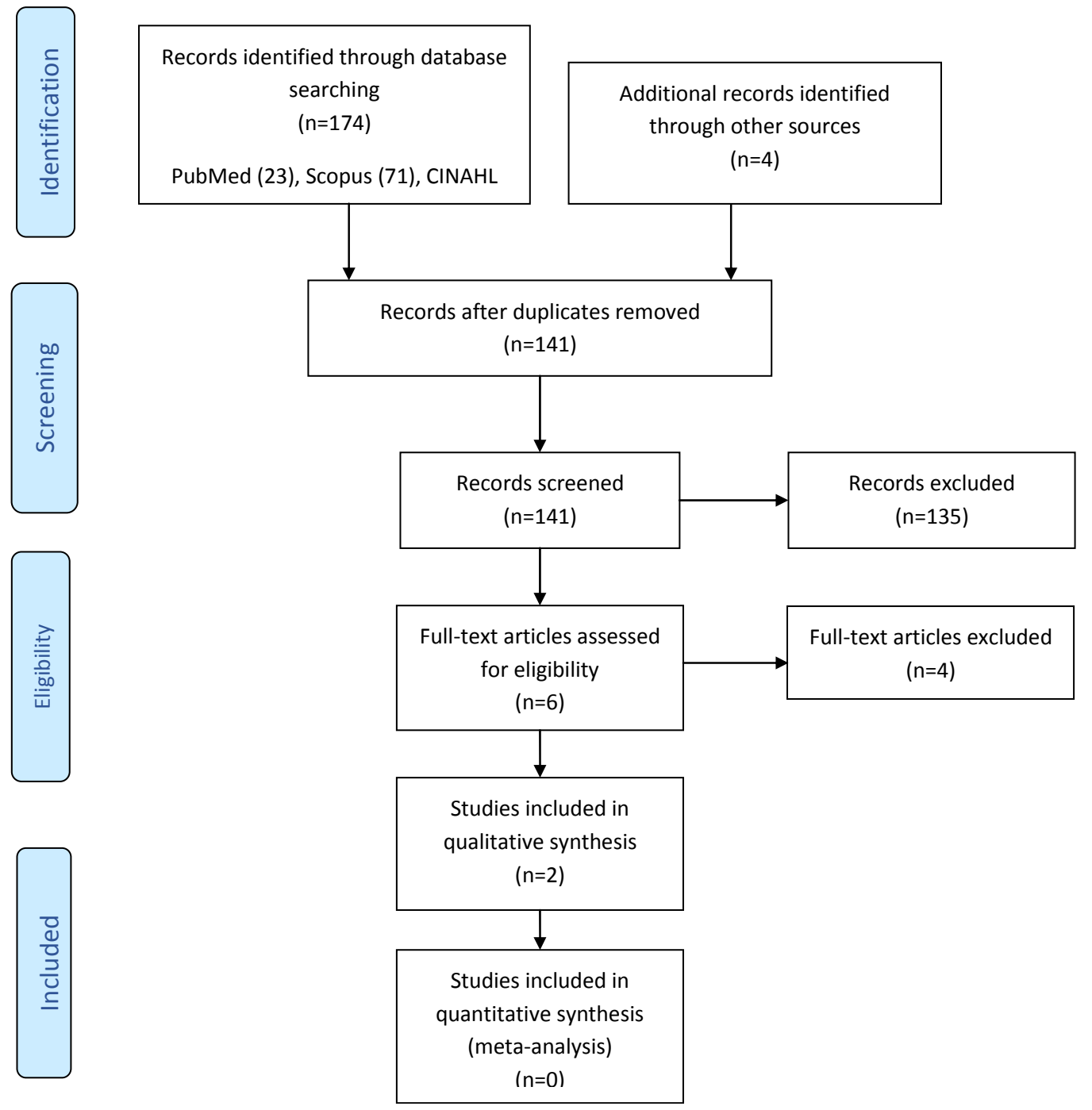

Fig. 1. PRISMA 2009 Flow Diagram

The reviewed trials were single-centric, two-arm parallel-group RCTs conducted in Turkey and Iran, and comprised of 100 participants, randomized into the treatment and comparison group $(15,16)$. The average age of the trial-participants was 52.49 years $(n=99)(15,16)$. The mean symptom duration was 5.53 months $(n=99)(15,16)$. Both trials recruited primary AC patients who were not suffering from any major (active) medical illness $(15,16)$. Attrition $(22 \% ; n=11)$ chiefly occurred in Ebadi et al.'s study (2017) (15). In both trials, while the intervention group received continuous mode US treatment (at $3 \mathrm{MHz}$ frequency and $1.5 \mathrm{~W} / \mathrm{cm}^{2}$ intensity) with some form of exercise therapy, the comparison group received sham US treatment with exercise therapy $(15,16)$. In one trial, besides the above, all participants received hot packs (16). The trialists of Ebadi et al. study and Dogru, Basaran \& Sarpel study, analysed data as an intention to treat and per-protocol respectively $(6,15,16)$. The trials assessed shoulder joint ROM (in degrees) in both the intervention groups for abduction, flexion, inner rotation, and outer rotation, at baseline and then in 10th session (time point 1 ; TP1) and third month (time point 2; TP2) following the intervention $(15,16)$. The trialists obtained the needed ethical clearance and participant consent for undertaking the trials $(15,16)$. Table 1 summarises the salient features of the trials $(15,16)$.

Next, we present the trials' risk of bias assessment (Table 2). In the study by Dogru, Basaran \& Sarpel (2008), the risk of selection bias remained unclear as there was no apparent mention of - how the random component of sequence generation was ensured and how the participants' allocation into different treatment groups was concealed from the researchers (16). In contrast, the use of randomly generated sealed opaque envelops along with the involvement of an outsider in randomising participants into the treatment groups reduced the risk of selection bias in the Ebadi et al. (2017) study (15). While the risk of performance bias was unclear in Dogru, Basaran \& Sarpel's study (16), this risk was low in Ebadi et al (15) study as a third individual blinded the participants and therapist in a concealed manner (by turning the US machine on or off) $(15,16)$. Blinding of the shoulder joint ROM measurer ensured low risk of detection bias in both trials $(15,16)$. The blinding of outcome assessors to the treatment 


\begin{tabular}{|c|c|c|c|c|c|c|}
\hline Study $^{*}$ & $\begin{array}{l}\text { Population } \\
\text { Study population (those ran- } \\
\text { domised): } 50 \\
\text { Dropout (after randomisation): } \\
1 \\
\text { Cause of drop-out: personal } \\
\text { reason (from sham US group at } \\
\text { early first week) }\end{array}$ & \multicolumn{2}{|c|}{ Intervention } & Methods & $\begin{array}{l}\text { Outcomes (post- } \\
\text { intervention) }\end{array}$ & Miscellaneous \\
\hline 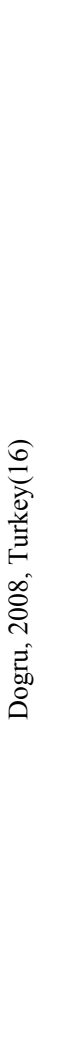 & $\begin{array}{l}\text { Study population (those ran- } \\
\text { domised): } 50 \\
\text { Dropout (after randomisation): } \\
1 \\
\text { Cause of drop-out: personal } \\
\text { reason (from sham US group at } \\
\text { early first week) } \\
\text { Age: between } 41-72 \text { years } \\
\text { Mean (SD) age: } 55.3 \text { ( } 7.6 \text { ) } \\
\text { years } \\
\text { Mean (SD) symptom duration: } \\
5.7 \text { (3.3) months } \\
\text { Sex (n=49): Male = } 21, \text { Female } \\
=28 \\
\text { Inclusion criteria: minimum } \\
\text { three months long shoulder } \\
\text { joint pain with no preceding } \\
\text { history of major trauma, } 25 \% \\
\text { or more loss in shoulder joint } \\
\text { ROM in all directions, visual } \\
\text { analogue scale score of } 40 \text { mm } \\
\text { in the affected shoulder joint, } \\
\text { no abnormality in shoulder x- } \\
\text { ray and absence of cancer, } \\
\text { arthritis or other medical cause } \\
\text { of joint pain like infection or } \\
\text { heart disease or coagulative } \\
\text { disorders. } \\
\text { Exclusion criteria: secondary } \\
\text { causes of AC like rotator cuff } \\
\text { tear, fracture, dislocation etc. }\end{array}$ & $\begin{array}{l}\text { Treatment group } \\
\text { Intervention: } \\
\text { 1. Hot pack, } \\
\text { 2. Exercise } \\
\text { program } \\
\text { (Codman's } \\
\text { exercise, active } \\
\text { ROM and } \\
\text { stretching exer- } \\
\text { cises) } \\
\text { 3. Continuous } \\
\text { US with } 3 \text { MHz } \\
\text { frequency and } \\
\text { 1.5 W/cm2 } \\
\text { intensity. SOS } \\
\text { analgesics. } \\
\text { Intervention } \\
\text { frequency: daily } \\
\text { for } 2 \text { weeks } \\
\text { except on week- } \\
\text { ends }\end{array}$ & $\begin{array}{l}\text { Control group } \\
\text { Intervention: } \\
\text { 1. Hot pack } \\
\text { 2. Exercise } \\
\text { program } \\
\text { (Codman's } \\
\text { exercise, active } \\
\text { ROM and } \\
\text { stretching } \\
\text { exercises) } \\
\text { 3. Sham US } \\
\text { (US device was } \\
\text { kept in switch- } \\
\text { off mode). } \\
\text { 4. SOS analge- } \\
\text { sics. } \\
\text { Intervention } \\
\text { frequency: } \\
\text { daily for } 2 \\
\text { weeks except } \\
\text { on weekends }\end{array}$ & $\begin{array}{l}\text { Design: } 2 \text { arm, paral- } \\
\text { lel group RCT; single } \\
\text { centred trial } \\
\text { Recruitment: partici- } \\
\text { pants were sequen- } \\
\text { tially numbered by } \\
\text { 2nd author and were } \\
\text { allocated to either US } \\
\text { therapy or sham US } \\
\text { therapy group. } \\
\text { Blinding: } \\
\text { 1st author: the out- } \\
\text { come assessor, was } \\
\text { blinded to treatment } \\
\text { 2nd author: sequen- } \\
\text { tially numbered the } \\
\text { patients and assigned } \\
\text { them to either US } \\
\text { therapy or sham US } \\
\text { therapy group; proba- } \\
\text { bly not blinded } \\
\text { 3rd author: role not } \\
\text { clear. } \\
\text { Participants: blinded } \\
\text { in sham US group } \\
\text { however, it's not } \\
\text { clear if those in inter- } \\
\text { vention group were } \\
\text { equally blinded to } \\
\text { treatment }\end{array}$ & $\begin{array}{l}\quad \text { intervention) } \\
\text { Outcome assessed: } \\
\text { shoulder joint ROM } \\
\text { in four directions } \\
\text { (abduction, flexion, } \\
\text { inner rotation, and } \\
\text { outer rotation) } \\
\text { Time points of } \\
\text { outcome assess- } \\
\text { ment: at 10th ses- } \\
\text { sion and third month } \\
\text { after intervention. } \\
\text { Results: Respective } \\
\text { improvement in } \\
\text { ROM from pre- } \\
\text { intervention to } 10 \text { th } \\
\text { session and 3rd } \\
\text { month post- } \\
\text { intervention were } \\
\text { statistically signifi- } \\
\text { cant in each of the } \\
\text { treatment groups. } \\
\text { Between treatment } \\
\text { group comparison of } \\
\text { ROM at two time } \\
\text { points after inter- } \\
\text { vention was signifi- } \\
\text { cant only for outer } \\
\text { rotation at } 10 \text { th } \\
\text { session after treat- } \\
\text { ment. }\end{array}$ & $\begin{array}{l}\text { Funding } \\
\text { source: not } \\
\text { clear } \\
\text { Ethical clear- } \\
\text { ance: obtained } \\
\text { Participant } \\
\text { consent: ob- } \\
\text { tained }\end{array}$ \\
\hline & & & & Analysis: per protocol & & \\
\hline
\end{tabular}

decreased the risk of detection bias in the Dogru and colleagues' trial $(6,16)$. Regarding the risk of attrition bias, the risk was low in Dogru, Basaran \& Sarpel (study (only one participant left the trial due to personal reasons) (16). But, in Ebadi et al. study, the risk of attrition bias was unclear as $22 \%$ of the participants were lost to follow up after receiving the allocated intervention and trialists imputed their ROM values by carrying the last observation forward (15). The risk of reporting bias was low, as the authors of both the trials reported results as per the description in the methodology section $(15,16)$. Lastly, we could not rule out the possibility of any ROM measurement-associated bias due to no clear mention of the reliability assessment of the outcome assessor/s $(15,16)$.

Subsequently, we depict the findings from the trials pertinent to the shoulder joint ROM in different directions at different time points $(15,16)$. The trials reported the mean and standard deviation (SD) of shoulder joint ROM, in degrees, in four different directions (abduction, flexion, inner rotation and outer rotation) at baseline, TP1 and TP2 $(15,16)$.

In the Dogru, Basaran \& Sarpel study, at baseline, compared to the control group, the ROM was worst in the real US group for passive abduction $(\mathrm{p}<0.050)$, flexion $(p<0.050)$, inner rotation $(p=0.001)$, and outer rotation $(p<0.001)(16)$. In contrast, the baseline ROM values among all of the tested directions did not vary statistically in the Ebadi et al. study (15).

In Dogru, Basaran \& Sarpel study, the within-group repeated measure of ROM in all four directions showed statistically significant improvement only at TP2 in each treatment group $(\mathrm{p}<0.0001)(16)$. This improvement in the Ebadi et al. was statistically significant for all directions of ROM (15).

Among the treatment groups, from the baseline, both trials also compared the change in ROM at TP1 and TP2 $(15,16)$. This post-pre-treatment improvement in Dogru and associates' study was larger in the real US treated group (compared to the sham-US group) - between TP1 and baseline (for flexion $(p<0.050)$, inner rotation $(0.002)$, and outer rotation $(\mathrm{p}<0.050))$ and between TP2 and baseline (for inner rotation $(\mathrm{p}=0.001)$ and outer rotation $(p<0.050))(16)$. Nonetheless, these differences in the four ROM directions did not vary between intervention groups in Ebadi et al. study (15).

The authors of Ebadi et al. study additionally examined if the ROM in different directions varied between the treatment groups based on any interaction with the following time intervals - baseline to TP1, TP1 to TP2 and baseline to TP2. They found a significant interaction between a time period (TP1 to TP2) and abduction, representing a larger improvement in the sham US group $(\mathrm{p}<0.050)(15)$. 
S. Saha, et al.

\begin{tabular}{|c|c|c|c|c|c|c|}
\hline \multirow[t]{2}{*}{ Study $^{*}$} & \multirow[t]{2}{*}{ Population } & \multicolumn{2}{|c|}{ Intervention } & \multirow[t]{2}{*}{ Methods } & \multirow{2}{*}{$\begin{array}{l}\text { Outcomes (post- } \\
\text { intervention) }\end{array}$} & \multirow[t]{2}{*}{ Miscellaneous } \\
\hline & & Treatment group & Control group & & & \\
\hline 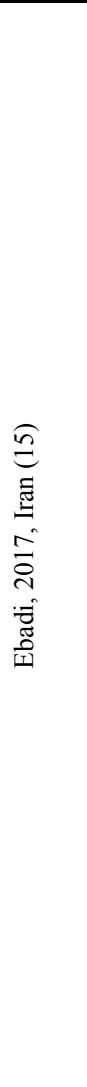 & $\begin{array}{l}\text { Study population: } 50 \\
\text { Dropout (after randomisa- } \\
\text { tion): } 11 \text { ( } 7 \text { in treatment } \\
\text { group and } 4 \text { in comparison } \\
\text { group) } \\
\text { Cause of dropout: personal } \\
\text { reasons not related to the } \\
\text { dissatisfaction or adverse } \\
\text { reaction to intervention } \\
\text { Age: between years } \\
\text { Mean (SD) age: } 49.74 \text { (7) } \\
\text { years } \\
\text { Mean (SD) symptom dura- } \\
\text { tion: } 5.36 \text { (1.9) months } \\
\text { Gender (n=50): male = 20, } \\
\text { female = } 30 \\
\text { Inclusion criteria: } 40 \text { to } 70- \\
\text { year-old } \\
\text { primary AC patients with } \\
\text { unilateral shoulder pain } \\
\text { and ROM restriction for } \\
\text { minimum } 3 \text { months with } \\
\text { no medical (like diabetes) } \\
\text { or psychological illness. } \\
\text { Moreover, the participant } \\
\text { should not have been treat- } \\
\text { ed with physiotherapy in } \\
\text { previous six months and } \\
\text { not on any analgesics. } \\
\text { Exclusion criteria: patients } \\
\text { not ready to consent fur- } \\
\text { ther to be in the study or } \\
\text { those not matching the } \\
\text { inclusion criteria. }\end{array}$ & $\begin{array}{l}\text { Included in final } \\
\text { analysis (n) }=25 \\
\text { Intervention: } \\
\text { Physical exercise } \\
\text { (stretching and } \\
\text { strengthening } \\
\text { exercises) } \\
\text { continuous US as } \\
3 \mathrm{MHz}, 1.5 \\
\mathrm{w} / \mathrm{cm} 2 \text { intensity } \\
\text { for } 6 \mathrm{~min} \text { duration } \\
\text { on the anterior } \\
\text { and posterior side } \\
\text { of the gleno- } \\
\text { humeral capsule. } \\
\text { Intervention fre- } \\
\text { quency: every } \\
\text { alternate day } \\
\text { except on week- } \\
\text { ends for } 10 \text { ses- } \\
\text { sions }\end{array}$ & $\begin{array}{l}\text { Included in final } \\
\text { analysis (n)= } \\
25 \\
\text { Intervention: } \\
\text { Physical exer- } \\
\text { cise (stretching } \\
\text { and strengthen- } \\
\text { ing exercises) } \\
\text { sham US (de- } \\
\text { vice light was } \\
\text { kept on with US } \\
\text { actually being } \\
\text { delivered) } \\
\text { Intervention } \\
\text { frequency: } \\
\text { every alternate } \\
\text { day except on } \\
\text { weekends for } 10 \\
\text { sessions }\end{array}$ & $\begin{array}{l}\text { Design: } 2 \text { arm, parallel } \\
\text { group RCT, single cen- } \\
\text { tred trial } \\
\text { Recruitment: random } \\
\text { allocation into interven- } \\
\text { tion and control group } \\
\text { using opaque sealed } \\
\text { envelopes; not done by } \\
\text { the authors } \\
\text { Blinding: double-blinded } \\
\text { (assessor, patient, and } \\
\text { therapist) } \\
\text { Analysis: intention to } \\
\text { treat }\end{array}$ & $\begin{array}{l}\text { Outcome assessed: } \\
\text { shoulder joint } \\
\text { ROM in four direc- } \\
\text { tions (abduction, } \\
\text { flexion, inner rota- } \\
\text { tion, and outer } \\
\text { rotation) } \\
\text { Time points of } \\
\text { outcome assess- } \\
\text { ment: at 10th ses- } \\
\text { sion and third } \\
\text { month after inter- } \\
\text { vention } \\
\text { Results: ROM } \\
\text { improved signifi- } \\
\text { cantly at both time } \\
\text { points in both of } \\
\text { the intervention } \\
\text { groups. However, } \\
\text { this change did } \\
\text { don't differ be- } \\
\text { tween the across } \\
\text { the treatment } \\
\text { groups. }\end{array}$ & $\begin{array}{l}\begin{array}{l}\text { Funding } \\
\text { source: not } \\
\text { clear }\end{array} \\
\text { Ethical clear- } \\
\text { ance: obtained } \\
\text { Participant } \\
\text { consent: ob- } \\
\text { tained }\end{array}$ \\
\hline
\end{tabular}

Table 2. Risk of bias table ${ }^{\#}$

\begin{tabular}{|c|c|c|c|}
\hline Study* & Domain & $\begin{array}{c}\text { Author's } \\
\text { judgement }\end{array}$ & Support for judgement \\
\hline \multirow{9}{*}{ 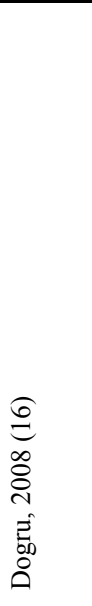 } & $\begin{array}{l}\text { Random sequence genera- } \\
\text { tion (selection bias) }\end{array}$ & Unclear risk & $\begin{array}{l}\text { Although participants were numbered sequentially it's not clear how the random component } \\
\text { of sequence generation was addressed (16). }\end{array}$ \\
\hline & $\begin{array}{l}\text { Allocation concealment } \\
\text { (selection bias) }\end{array}$ & Unclear risk & Not mentioned clearly \\
\hline & $\begin{array}{l}\text { Blinding of participants } \\
\text { and personnel (perfor- } \\
\text { mance bias) }\end{array}$ & Unclear risk & $\begin{array}{l}\text { Since the authors mentioned that the US device was not turned on in the sham US treated } \\
\text { group the participants were plausibly blinded of the intervention they received, and the blind- } \\
\text { ing was not broken. However, it is not clear if the intervention provider/s were equally blind- }\end{array}$ \\
\hline & $\begin{array}{l}\text { Outcome: ROM (active or } \\
\text { passive) }\end{array}$ & & ed $(16)$ \\
\hline & $\begin{array}{l}\text { Blinding of outcome } \\
\text { assessment (detection } \\
\text { bias) }\end{array}$ & Low risk & $\begin{array}{l}\text { Outcome assessor was blinded to the treatments, as reported in a Cochrane review (authors } \\
\text { of this review communicated with the trial authors) }(6,16) \text {. }\end{array}$ \\
\hline & Outcome: ROM (passive) & & \\
\hline & $\begin{array}{l}\text { Incomplete outcome data } \\
\text { (attrition bias) }\end{array}$ & Low risk & $\begin{array}{l}\text { Only one participant left the study intervention group which is unlikely to bias the outcome } \\
\text { measurements (16). }\end{array}$ \\
\hline & $\begin{array}{l}\text { Selective reporting (re- } \\
\text { porting bias }\end{array}$ & Low risk & $\begin{array}{l}\text { Although a protocol was not available, authors have prespecified about the ROM measure- } \\
\text { ments at } 10 \text { th session and } 3 \text { months post-intervention and have reported all outcome in Table } \\
2 \text { of their paper (16). }\end{array}$ \\
\hline & Other bias & Unclear risk & There is no mention about intra-rater reliability of the outcome assessor (16). \\
\hline
\end{tabular}

A meta-analysis and subsequent assessment for any heterogeneity and publication bias were beyond the scope of this review due to its qualitative nature.

Finally, we cite some of the pitfalls that might have plausibly biased the results of the trials $(15,16)$. For instance, in the Dogru and associates' study, at baseline, the real US treated group had a worse shoulder joint ROM in each of the four directions (whereas these values were comparable in the other trial) $(15,16)$. Furthermore, its treatment group were less compliant with home exercises, compared to the control group (16). Conversely, the main concern in the Ebadi et al. study was the missing ROM values of those who were lost to follow up (15). For those the last observation was carried forward, we can't be absolutely certain of the true ROM values in different directions if all participants had continued to follow up until 


\begin{tabular}{|c|c|c|c|}
\hline \multicolumn{4}{|c|}{ Table 2.Ctd } \\
\hline Study* & Domain & $\begin{array}{c}\text { Author's } \\
\text { judgement }\end{array}$ & Support for judgement \\
\hline \multirow{7}{*}{ 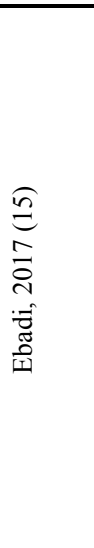 } & $\begin{array}{l}\text { Random sequence generation } \\
\text { (selection bias) }\end{array}$ & Low risk & Random component was clearly evident in the sequence generation process (15). \\
\hline & $\begin{array}{l}\text { Allocation concealment (selec- } \\
\text { tion bias) }\end{array}$ & Low risk & $\begin{array}{l}\text { Allocation was likely to be concealed since a statistician was involved who was } \\
\text { not the involved in recruitment process (15). }\end{array}$ \\
\hline & $\begin{array}{l}\text { Blinding of participants and } \\
\text { personnel (performance bias) } \\
\text { Outcome: ROM (active) }\end{array}$ & Low risk & $\begin{array}{l}\text { The assistant played a crucial role in maintaining blinding of participants and } \\
\text { therapist who provided the continuous US therapy (15). }\end{array}$ \\
\hline & $\begin{array}{l}\text { Blinding of outcome assessment } \\
\text { (detection bias) } \\
\text { Outcome: ROM (active) }\end{array}$ & Low risk & Outcomes assessor was likely to be blinded (15). \\
\hline & $\begin{array}{l}\text { Incomplete outcome data (attri- } \\
\text { tion bias) }\end{array}$ & Unclear risk & $\begin{array}{l}22 \%(n=11) \text { of the participants were lost to follow up. Moreover, the method of } \\
\text { imputation is likely to create. }\end{array}$ \\
\hline & $\begin{array}{l}\text { Selective reporting (reporting } \\
\text { bias) }\end{array}$ & Low risk & $\begin{array}{l}\text { Although a protocol was not available, the authors reported the outcome entirely as } \\
\text { described in the methodology section (15). }\end{array}$ \\
\hline & Other bias & Unclear & $\begin{array}{l}\text { There is no mention about the number of active shoulder movement assessors } \\
\text { involved and there interrater or intra-rater reliability in context of active ROM } \\
\text { measurement (15). }\end{array}$ \\
\hline
\end{tabular}

the end (15). Perhaps, an accompanying analysis (like a worst-case scenario assessment or vice versa) would have accounted better for the statistically significant improvement observed in the respective treatment groups.

\section{Discussion}

We found two single centred trials, published between Feb 1979 to Feb 2019, that compared the therapeutic effect of continuous mode US with non-electrotherapeutic modalities on shoulder joint ROM in four directions (abduction, flexion, inner rotation and outer rotation) among 100 primary AC patients $(15,16)$. In Dogru and associate's study, the selection bias and performance bias remained unclear (16). In contrast, in Ebadi et al.'s study, the risk of bias was unclear for attrition bias (15). In both trials, the inter-rater or intra-rater reliability of outcome assessor for ROM measurement was not clear $(15,16)$. Remaining components of the risk of bias assessed in the trials were at a lower risk $(15,16)$. Within each of the treatment groups, there was a significant improvement in ROM in different directions in both trials $(15,16)$. However, only in the Dogru et al. study, there was some evidence of greater improvement in ROM in all directions (except abduction) at the follow-up time points (16).

Then we explore the context in light of what is known. It seems apparent from the literature search that none of the contemporary review articles have researched the effects of continuous mode US therapy on shoulder joint kinesis in primary AC patients. Existing recent researches mainly focused on the effects of therapeutic US on a broader context like musculoskeletal problems or shoulder pathologies in general $(17,18)$. We could retrieve only one review paper (published in 2014) that specifically studied the effects of therapeutic US in AC and concluded that the contemporary evidence regarding the effectiveness of US therapy on active shoulder joint ROM is inconclusive (6). Compared to that review (6), we presented here more updated evidence (a literature search up to Feb 2019) about a specific mode of US therapy (continuous mode) on shoulder joint kinesis (irrespective to if ROM was measured actively or passively). A search in the PROSPERO database revealed two ongoing trials that are investigating the effect of therapeutic US on shoulder joint
$\operatorname{ROM}(19,20)$. However, contrasted to ours, these reviews are unlikely to be specifically studying the effect of continuous mode-US $(19,20)$.

Next, regarding the implications of this paper, therapists like osteopaths, physiotherapists, and physicians may find this review useful to decide the trade-offs between the therapeutic cost of continuous mode-US treatment versus its benefit in ROM improvement while advising the primary AC patients in light of the current evidence. Similarly, the primary AC patients, seeking or receiving continuous mode of US therapy might also find our review helpful to understand the amount of improvement in shoulder joint mobility to be expected, based on the current evidence. Likewise, policymakers and key stakeholders of health systems might find our finding worthful in deciding how much of the resources (financial, logistic) should flow in implementing or continuing continuous mode of US therapy to benefit the primary AC patients. Lastly, to produce more rigorous evidence in the context, this review may encourage future trialists to conduct multicentric large clinical trials for a relatively long duration plus a good study design (to ensure a low risk of bias).

Lastly, we illustrate the limitations of our review. At the study level, the trials are likely to be underpowered due to their relatively small sample sizes $(15,16)$. Additionally, the single centric design of the trials is likely to decrease the external validity. Then, at the outcome level, the trials primarily suffered from unclear risk of selection bias (16), performance bias (16), and attrition bias (15). Ultimately, at the review level, we could not search for all possible electronic databases (due to our limited resources) which limited the scope of our search. Furthermore, our search was confined to language and time period restrictions.

\section{Conclusion}

The results of the reviewed trials were not identical, and each was accompanied by their respective weaknesses. In the absence of rigorously conducted large multicentric trials of a relatively longer duration, it is hard to conclude decisively if the continuous mode of US treatment is beneficial in improving the ROM in different directions in primary AC patients. 


\section{Acknowledgements}

This paper has been prepared by the authors independently and it is not related to their affiliated institutions.

\section{Conflict of Interests}

The authors declare that they have no competing interests.

\section{References}

1. Mezian K, Chang KV. Frozen Shoulder [Updated 2018 Oct 27]. StatPearls [Internet] Treasure Isl StatPearls Publ [Internet]. 2018;1-6. Available from: https:/www.ncbi.nlm.nih.gov/books/NBK482162/\# ncbi_dlg_citbx_NBK482162

2. Salvatore M, Latte C, Milano G, Grasso A. Adhesive capsulitis. Shoulder Arthrosc Princ Pract. 2014;29(6):365-77.

3. Neviaser SA, Neviaser JR. Adhesive Capsulitis of the Shoulder. Am Acad Orthop Surg. 2011;19(9):536-42.

4. Hsu JE, Anakwenze OA, Warrender WJ, Abboud JA. Current review of adhesive capsulitis. J Shoulder Elb Surg [Internet]. 2011;20(3):502-14. Available from: http://dx.doi.org/10.1016/ j.jse.2010.08.023

5. Ramirez J. Adhesive Capsulitis: Diagnosis and Management. Am Fam Physician. 2019 Mar;99(5):297-300.

6. Page MJ, Green S, Kramer S, Johnston RV, McBain B, Buchbinder R. Electrotherapy modalities for adhesive capsulitis (frozen shoulder). Cochrane Database Syst Rev [Internet]. 2014 Oct 1;(10). Available from: http://doi.wiley.com/10.1002/14651858.CD011324

7. Zeng $\mathrm{C}$, Li $\mathrm{H}$, Yang $\mathrm{T}$, Deng ZH, Yang $\mathrm{Y}$, Zhang $\mathrm{Y}$, et al. Effectiveness of continuous and pulsed ultrasound for the management of knee osteoarthritis: a systematic review and network meta-analysis. Osteoarthr Cartil [Internet]. 2014;22(8):1090-9. Available from: http://www.sciencedirect.com/science/article/pii/ S1063458414011510

8. Aly Saber A, Saber A. Therapeutic Ultrasound: Physiological Role, Clinical Applications and Precautions. J Surgery Spec Issue Minim Invasive Minim Access Surg [Internet]. 2017;5(1):61-9. Available from: http://www.sciencepublishinggroup.com $/ \mathrm{j} / \mathrm{js}$

9. Shadmehr A, Astaneh HN. Continuous vs. pulse ultrasound therapy on the flexibility of short hamstring muscles. In: 2009 IEEE International Ultrasonics Symposium [Internet]. IEEE; 2009. p. 1310 3. Available from: http://ieeexplore.ieee.org/document/5441427/

10. Kapci Yildiz S, Ünlü Özkan F, Aktaș İ, Şilte AD, Yilmaz Kaysin M, Bilgin Badur N. The effectiveness of ultrasound treatment for the management of kneeosteoarthritis: a randomized, placebo-controlled, double-blind study. TURKISH J Med Sci [Internet]. 2015;45:118791. Available from: http://online.journals.tubitak.gov.tr/openDoiPdf. htm?mKodu=sag-1408-81

11. Morishita K, Karasuno H, Yokoi Y, Morozumi K, Ogihara H, Ito T, et al. Effects of therapeutic ultrasound on range of motion and stretch pain. J Phys Ther Sci [Internet]. 2014 May;26(5):711-5. Available from: http://www.ncbi.nlm.nih.gov/pubmed/24926137

12. Shah SGS, Farrow A. Trends in the availability and usage of electrophysical agents in physiotherapy practices from 1990 to 2010: a review. Phys Ther Rev. 2012;17(4):207-26.

13. Liberati A, Altman DG, Tetzlaff J, Mulrow C, Gøtzsche PC, Ioannidis JPA, et al. The PRISMA statement for reporting systematic reviews and meta-analyses of studies that evaluate health care interventions: explanation and elaboration. J Clin Epidemiol. 2009.

14. Higgins J, Green S (editors). Cochrane Handbook for Systematic Reviews of Interventions Version 5.1.0 [updated March 2011]. The Cochrane Collaboration. The Cochrane Collaboration. 2011.

15. Ebadi S, Forogh B, Fallah E, Babaei Ghazani A. Does ultrasound therapy add to the effects of exercise and mobilization in frozen shoulder? A pilot randomized double-blind clinical trial. J Bodyw Mov Ther [Internet]. 2017 Oct;21(4):781-7. Available from: https://doi.org/10.1016/j.jbmt.2016.11.013

16. Dogru H, Basaran S, Sarpel T. Effectiveness of therapeutic ultrasound in adhesive capsulitis. Joint Bone Spine [Internet]. 2008 Jul;75(4):445-50. Available from: http://www.embase.com/search/ results? subaction $=$ viewrecord \&from $=$ export\&id $=$ L50092497

17. Baker KG, Robertson VJ, Duck FA. A Review of Therapeutic
Ultrasound. J Women's Heal Phys Ther. 2013;34(3):111-8.

18. Alexander LD, Gilman DRD, Brown DR, Brown JL, Houghton PE. Exposure to Low Amounts of Ultrasound Energy Does Not Improve Soft Tissue Shoulder Pathology: A Systematic Review. Phys Ther. 2010;90(1):14-25.

19. Ferreira G, Py R, Silva C da, Santiago C, Baroni B, Robinson C, et al. Electrotherapy, phototherapy, thermotherapy and therapeutic ultrasound for the management of adhesive capsulitis of the shoulder: a systematic review. PROSPERO. 2014;CRD4201400.

20. Zhang J, Zhong S, Cheng R, Tan T, Wu M, Li J, et al. Comparative efficacy and tolerability of nonsurgical treatments for adhesive capsulitis: a network meta-analysis. PROSPERO. 2018;CRD4201811. 